\title{
Obituary
}

Vincent Barras, Hubert Steinke

\section{Marcel H. Bickel (14.10.1927-1.8.2017)}

Marcel Bickel, editor-in-chief of Gesnerus 1993-2001, died on $1^{\text {st }}$ of August 2017.

After his studies of chemistry and biochemistry at the University of Basel he stayed for several years at the Istituto Superiore di Sanità in Rome and the NIH in Bethesda. Back in Switzerland, now at the University of Bern, he was appointed lecturer (Privatdozent) in 1967, full professor in 1971 and head of the Institute of Pharmacology in 1977. His resarch focused on drug metabolism and pharmacokinetics, psychopharmacology and toxicology.

Already as a young scientist - and not least thanks to his uncle Henry E. Sigerist - Bickel developed a keen interest in the historical perspective on medicine in general and on pharmacology in particular. From the 1960s onwards and especially after his retirement in 1993 he published a number of historical works, most notably books on the biochemist Marcel Nencki (1972), the history of experimental pharmacology (2000), the historiography of medicine (2007) and - very recently - early women physicians (2017). Within the community of medical historians he is presumably best known as editor of some 3000 letters of Sigerist, an invaluable source for $20^{\text {th }}$ century history of medicine.

Marcel Bickel was a key actor in the development and professionalization of the history of medicine in Switzerland. It is largely thanks to his commitment that a proper chair and institute of the history of medicine was installed at the University of Bern in the 1970s. As president of the Swiss Society for the History of Medicine and Sciences (1987-1989) and especially as editorin-chief of Gesnerus 1993-2001 he guaranteed stability in the continuing transformation of our academic profession. We will remember Marcel Bickel not only as an important member of our community but also as warmhearted friend and colleague whose constructive criticism and encouragement inspired many of us. 


\section{Major publications on history of medicine and pharmacy}

Marceli Nencki, 1847-1901 (Bern 1972), 102 p.

(with C.Bachmann): History of Drug Metabolism: the First Half of the $20^{\text {th }}$ Century, Drug Metabolism Review 16 (1986) 185-253

Die Entwicklung zur experimentellen Pharmakologie 1790-1850: Wegbereiter von Rudolf Buchheim (Basel 2000), 158 p.

Die Lehrbücher und Gesamtdarstellungen der Geschichte der Medizin 1696-2000: ein Beitrag zur medizinischen Historiographie (Basel 2007), 303 p.

Die ersten Ärztinnen in Europa und Amerika und der frühe Feminismus (18501900) (Bern 2017), 173 p.

\section{Correspondences of Henry E. Sigerist}

Henry E. Sigerist: Vier ausgewählte Briefwechsel mit Medizinhistorikern der Schweiz (Bern 2008), $596 \mathrm{p}$.

Correspondence: Henry E. Sigerist-Charles Singer, 1920-1956 (London 2010), 346 p.

Henry E. Sigerist: Correspondences with Welch, Cushing, Garrison and Ackerknecht (Bern 2010), $488 \mathrm{p}$.

Online-edition of Henry E. Sigerist Correspondences with John F. Fulton, Alan Gregg, Chauncey D. Leake, Adolf Meyer, Milton I. Roemer, Richard H. Shryock, Owsei Temkin, and Gregory Zilboorg at www.img.unibe.ch (2013)

See also the congratulations to his $70^{\text {th }}$ and $80^{\text {th }}$ birthday in Gesnerus 54 (1997) 259-260 and 64 (2007) 248. 